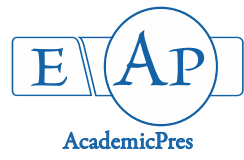

\title{
Bio-cultural Diversity and Ethnobotanic Utility of Indigenous Rice (Oryza sativa L.) in Lakhimpur District, Assam, India
}

\author{
Tonlong WANGPAN, Hemprova GOGOI, Taka TAPI, \\ Sumpam TANGJANG*
}

\author{
Rajiv Gandhi University, Rono Hills, Doimukh-791112, Arunachal Pradesh, India; sumpam@gmail.com ("corresponding author); \\ twangpan@gmail.com; hemgogoi044@gmail.com;aka7daniel@gmail.com
}

\begin{abstract}
The traditional landraces of rice plant had a major role in building socio-economic status of rural poor. The present study deals with the diversity and ethnobotanic significance of indigenous landraces of rice in Lakhimpur district of Assam, India. Altogether, twenty-one indigenous landraces of rice were collected during the present study. Each class having important role to play, the major classes of rice include glutinous, common rice and aromatic rice. Other than being a staple food, rice and its products are still frequently used by rural folk in various festivals, religious and social ceremonies in the form of sweets, cakes, snacks and beverages. Bora-dhan was reported with the highest use value. Based on grain's qualitative and quantitative traits, the obtained dendrogram contains four different clusters; while, the OTUs (Operational taxonomic unit) present in a cluster display morphological similarity. The dendrogram also illustrated diversified distribution of grains in this region. The study also reveals the profound relationship of people with the traditional landraces of rice. The ethnic farmers should be made aware to promote on-farm conservation of crop diversity, before it is lost under the debris of modernization.
\end{abstract}

Keywords: agro-ecology; ethnobotany; germplasm; indigenous rice; landraces

\section{Introduction}

Rice, the most important staple food crop of India has been cultivated in Asia for several thousand years. It is a major source of calories for about 60 per cent of the world population (Veeresh et al., 2011). Rice is also considered to be a good source of carbohydrates and other essential components, including $\gamma$-oryzanol (Rahman et al., 2006). Besides having nutritive value, rice is also known to have medicinal values (Das and Oudhia, 2001).

The traditional crop landraces play dynamic roles in the expression of native biological and cultural diversity via their central position in the genetic resource base, agroecosystems and social heritage (Pfeiffer et al., 2006). The traditional landraces of rice have regained their importance in the last decade of the $20^{\text {th }}$ century, when the hybrid seeds failed to give the desired result being attacked by different infectious pests, diseases and other climatic hazards (Mohanty et al., 2011). Due to increasing social and environmental pressures, these local germplasm, indigenous knowledge system and traditional agriculture practices may vanish within no time (Wangpan and Tangjang, 2012). So, the collection, conservation and maintenance of traditional varieties is a grave issue because of their valuable traits i.e. resistance to several stresses. The paper aims to explore the diversity of indigenous rice landraces and aassociated valuable indigenous knowledge in molding the life of indigenous people.

\section{Materials and Methods}

\section{Study area and ethnic community}

Lakhimpur district is situated between $26^{\circ} 48^{\prime}$ and $27^{\circ}$ $53^{\prime}$ Northern latitude and $93^{\circ} 42^{\prime}$ and $94^{\circ} 24^{\prime}$ East longitude of Assam (Fig. 1). The district is blessed with luxurious flora and fauna, stunning landscape and pouring rivers. Tropical forest and several river systems characterize the geography of this region. The major river of the district is Subansiri, while rivulet Kakoi Nodi flows inside the villages that give fertile land for wet-rice cultivation and adequate water for irrigation. The villages such as, Bihpuria, Dhakuakhana, Kadam, Naobaicha and Narayanpur are actively involved in paddy cultivation.

Ahom, Chutia, Kalita and Koch are the major castes and Miri, Kachari, Boro, Adivashi, and Hazong are some prominent tribes inhabiting the district. With rich social norms, customs, beliefs, faiths and practices each of these caste and tribes occupies a distinct geographical area. Agriculture is the primary occupation and irrigated settled type of paddy cultivation is generally preferred all around the region. 


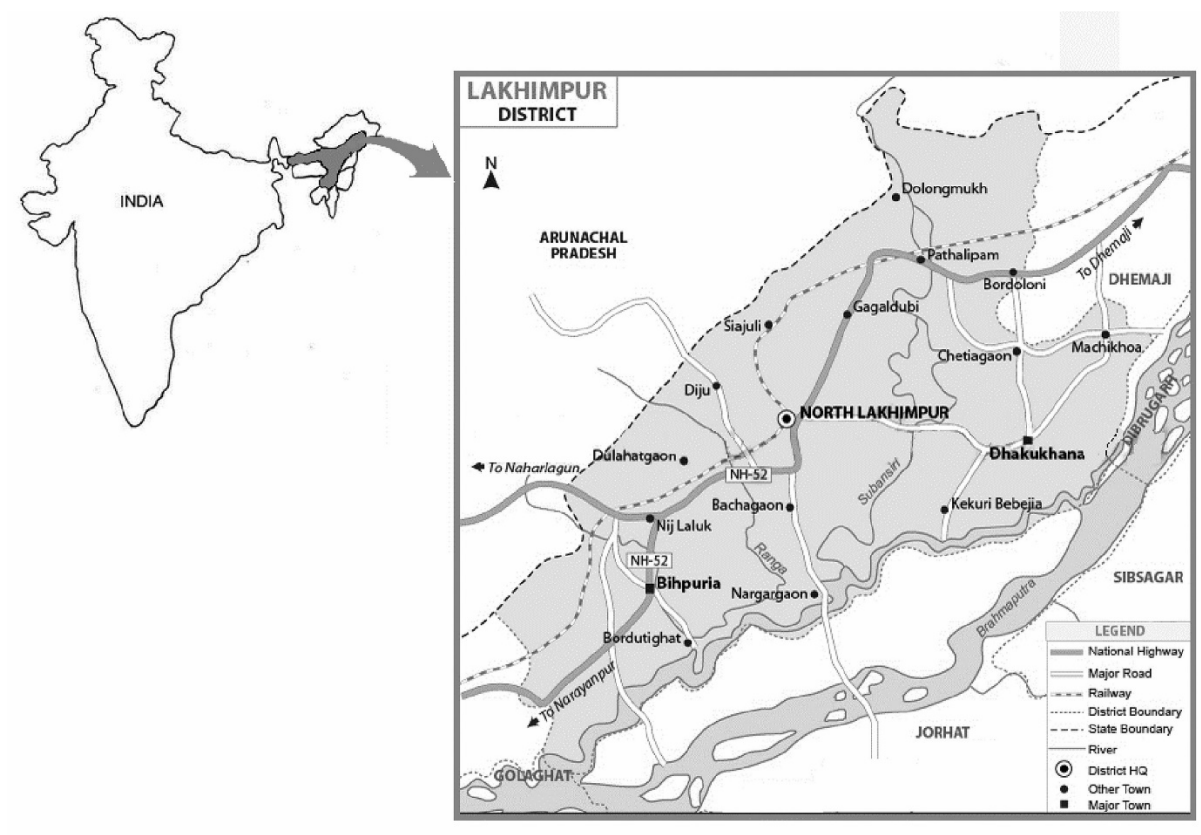

Fig. 1. Map of Lakhimpur district, Assam, India

\section{Gathering and analysis of data}

The household survey of randomly selected villages was conducted with the help of structured questionnaire to collect detail information on paddy and its cultivation (Wangpan et al., 2018). The questions also covered a wide array of subject related to the land use pattern, agriculture, pest management techniques and role of rice in rituals. Information was collected directly from the villagers including village elders on the traditional methods of rice cultivation, soil type used for cultivation, season for propagation, traditional harvesting seasons and their ethnobotanic utilizations. The rice samples were collected to obtain necessary information on seed morphology.

The use value (UV) demonstrates the relative importance of the rice landraces known locally and was calculated using the following formula (Gazzaneo et al., 2005).

The primary data was analysed with the help of standard statistical tools. Vernier scale was used to measure the quantitative variables. The mean value of the variables was considered in this study. Cluster analysis of qualitative and quantitative grain morphological characters was also performed to study the varietal diversity. All the calculations and statistical analysis was performed using XLSTAT version 2014.

\section{Results and Discussion}

\section{Diversity of indigenous rice}

Altogether, twenty-one indigenous and two hybrids (Ranjit and Bakhanti) varieties were collected from the study site (Table 1). Farmers' preference of rice varieties based on varietal attributes showed that in case of most of the attributes, preference was heavily tilted towards HYVs in the study area (Borthakur, 2015). Such preference may however, have led to decreased in population of native rice varieties in most of the villages. Except Kakuwa-bao, which is restricted to Kadam Laimakuri village, other varieties were common to other villages.

Based on the characteristics of grains, the rice has been classified as Bora (glutinous), Chawkua (instant or common rice), and Joha (aromatic rice). Based on season of cultivation, farmers have categorized the traditional rice into Bao-dhan and Sali-dhan. Bao-dhan was sown in the onset of May and harvested in the month of November. The common characteristics shared by this category include photoperiod insensitive, cold tolerant, sowing of seeds directly in the marshy land with minimal tillage and presence of awn. Sali-dhan, however, are sown in beginning of June and harvested by the end of November. The characteristics shared by this category include photoperiod sensitivity, transplanted under variable water depth (up to $40 \mathrm{~cm}$ ) and also possess aromatic property. Unlike Baodhan, the seeds needed to be sown in nursery, prior to transplantation.

The ethnic communities generally prefer seed morphology (size, shape and color), texture (glutinous, plain and tender), and presence of awn, flavor and aroma as means of identification (Table 1). The rice variety Sakuwa, with the length of $1.04 \pm 0.09 \mathrm{~cm}$ was recorded with the longest grain; while the variety Kon-joha with $0.6 \pm 0.07 \mathrm{~cm}$ was the shortest. The grain of Aakihali with $0.43 \pm 0.03 \mathrm{~cm}$ breadth was recorded to be the broadest, whereas, the grain of variety Bioi with $0.21 \pm 0.03 \mathrm{~cm}$ breadth was record to be the thinnest. Sakuwa proves to be the heaviest grain with $71.80 \pm 5.4$ gram per thousand grain weights, while Konjoha was scored to be the lightest with only $46.50 \pm 4.5$ gram per thousand grain weights.

The outer (hull) and inner (kernel) color of glumes can be taken as a reference to differentiate between the varieties. The outer portion of glumes i.e. hull or husk of different 
140

varieties have different colors which can be distinguish into yellow, light yellow, light brown, black, yellowish brown, reddish brown and red. Yet, 55\% of the grains have yellow hull. Except five varieties i.e. Bora-dhan (white), Kakuwabao (brown), Sakua (brown), Bioi (brown) and Amona (light red), rest of the varieties have off-white kernel color.

The boiled rice possessing best texture, good flavor and aroma are generally preferred during marriage and other social gatherings. The landraces such as, Kon-joha, Pokikola and Aampakhi were aromatic in nature, while only Boradhan was reported with the glutinous property.

Awn with 3 different colors i.e. yellow, black and brown color was recorded from varieties (Biria-vonga, Kolahali and Kakuwa-bao etc.). Among them, Kokuwa-bao with $5.5 \pm$ $0.09 \mathrm{~cm}$ possesses longest awn, whereas, Amona with $1.2 \pm$
$0.05 \mathrm{~cm}$ has shortest awn. However, awn colour may vary even among the same variety of grains.

Based on grain's qualitative and quantitative traits, the obtained dendrogram contains four different clusters (Fig. 2). Cluster 1 having only one OTU (Sakhuwa), Cluster two containing highest (10) number of OTUs (Kakowa-bao, Kolahali, Henduri-hali, Huwakmoni, Aakihali, Amona, Ampakhi, Bordubi, Holpun, Biri-bhonga and Bora-dhan), Cluster 3 with 5 OTUs (Kon-joha, Bioi, Ijong, Bali-dhan and Haru-jahinga) and Cluster 4 with 3 OTUs (Pakikula, Borjahinga and Bahador). These OTUs (rice variety) present in a cluster shares morphological similarity (grain related). Further, the dendrogram also illustrated diversified distribution of grains in this region.

Table 1. Diversity of rice and seed description of the collected indigenous rice varieties from Lakhimpur, Assam

\begin{tabular}{|c|c|c|c|c|c|c|c|c|c|c|c|}
\hline \multirow{2}{*}{$\begin{array}{c}\text { Sl. } \\
\text { No. }\end{array}$} & \multirow{2}{*}{ Local name } & \multirow{2}{*}{ Length } & \multirow{2}{*}{ Breadth } & \multirow{2}{*}{$\begin{array}{c}\text { Length/breadth } \\
\text { ratio } \\
\end{array}$} & \multirow{2}{*}{$\begin{array}{l}1000 \\
\text { GW }\end{array}$} & \multirow{2}{*}{$\begin{array}{c}\text { Awn } \\
\text { length }\end{array}$} & \multicolumn{2}{|c|}{ Glume color } & \multirow{2}{*}{ Texture } & \multirow{2}{*}{ Aromatic } & \multirow{2}{*}{ UV } \\
\hline & & & & & & & Hull & Kernel & & & \\
\hline 1 & Aakihali & $\begin{array}{c}0.80 \pm \\
0.02\end{array}$ & $\begin{array}{c}0.43 \pm \\
0.03\end{array}$ & 2 & $\begin{array}{c}57.50 \pm \\
2.7\end{array}$ & $\begin{array}{c}1.52 \pm \\
0.03\end{array}$ & Y & OW & NG & No & 0.34 \\
\hline 2 & Aampakhi & $\begin{array}{c}0.92 \pm \\
0.05\end{array}$ & $\begin{array}{c}0.33 \pm \\
0.03\end{array}$ & 3 & $\begin{array}{c}57.00 \pm \\
2.6\end{array}$ & - & $\mathrm{Y}$ & OW & NG & Yes & 0.67 \\
\hline 3 & Amona & $\begin{array}{c}0.74 \pm \\
0.06\end{array}$ & $\begin{array}{c}0.32 \pm \\
0.03\end{array}$ & 2.3 & $\begin{array}{c}57.50 \pm \\
2.3\end{array}$ & $\begin{array}{c}1.21 \pm \\
0.05\end{array}$ & $\mathrm{Lb}$ & $\mathrm{Lr}$ & NG & No & 0.45 \\
\hline 5 & Bali-dhan & $\begin{array}{c}0.85 \pm \\
0.08\end{array}$ & $\begin{array}{c}0.33 \pm \\
0.04\end{array}$ & 2.7 & $\begin{array}{c}52.50 \pm \\
5.3\end{array}$ & - & $\mathrm{Y}$ & OW & NG & No & 0.67 \\
\hline 6 & Biri bhonga & $\begin{array}{c}0.86 \pm \\
0.04\end{array}$ & $\begin{array}{c}0.32 \pm \\
0.05\end{array}$ & 2.7 & $\begin{array}{c}61.90 \pm \\
3.4\end{array}$ & $\begin{array}{c}2.53 \pm \\
0.07\end{array}$ & $\mathrm{Y}$ & OW & NG & No & 0.45 \\
\hline 7 & Bora-dhan & $\begin{array}{c}0.93 \pm \\
0.06\end{array}$ & $\begin{array}{c}0.44 \pm \\
0.07\end{array}$ & 2.2 & $\begin{array}{c}59.80 \pm \\
2.3\end{array}$ & - & $\mathrm{Lb}$ & W & G & No & 0.89 \\
\hline 8 & Bordubi & $\begin{array}{c}0.82 \pm \\
0.05\end{array}$ & $\begin{array}{c}0.35 \pm \\
0.09\end{array}$ & 2.7 & $\begin{array}{c}56.50 \pm \\
5.6\end{array}$ & - & $\mathrm{Y}$ & OW & NG & No & 0.78 \\
\hline 9 & Borjahinga & $\begin{array}{c}0.74 \pm \\
0.03\end{array}$ & $\begin{array}{c}0.32 \pm \\
0.07\end{array}$ & 2.3 & $\begin{array}{c}52.60 \pm \\
4.8\end{array}$ & - & $\mathrm{Br}$ & OW & NG & No & 0.25 \\
\hline 10 & Haru-jahinga & $\begin{array}{c}0.83 \pm \\
0.02\end{array}$ & $\begin{array}{c}0.32 \pm \\
0.05\end{array}$ & 2.7 & $\begin{array}{c}52.40 \pm \\
4.3\end{array}$ & - & $\mathrm{Lb}$ & OW & NG & No & 0.27 \\
\hline 11 & Henduri-hali & $\begin{array}{c}0.75 \pm \\
0.06\end{array}$ & $\begin{array}{c}0.33 \pm \\
0.04\end{array}$ & 2.3 & $\begin{array}{c}57.00 \pm \\
5.7\end{array}$ & - & $\mathrm{R}$ & OW & NG & No & 0.34 \\
\hline 12 & Holpun & $\begin{array}{c}0.82 \pm \\
0.07\end{array}$ & $\begin{array}{c}0.34 \pm \\
0.03\end{array}$ & 2.7 & $\begin{array}{c}55.50 \pm \\
5.6\end{array}$ & - & $\mathrm{Y}$ & OW & NG & No & 0.37 \\
\hline 13 & Huwakmoni & $\begin{array}{c}0.84 \pm \\
0.09\end{array}$ & $\begin{array}{c}0.32 \pm \\
0.04\end{array}$ & 2.7 & $\begin{array}{c}55.40 \pm \\
3.8\end{array}$ & - & $\mathrm{Rb}$ & OW & NG & No & 0.32 \\
\hline 14 & Ijong & $\begin{array}{c}0.75 \pm \\
0.06\end{array}$ & $\begin{array}{c}0.31 \pm \\
0.07\end{array}$ & 2.3 & $\begin{array}{c}51.00 \pm \\
3.2\end{array}$ & - & $\mathrm{Y}$ & OW & NG & No & 0.38 \\
\hline 15 & Kakowa-bao & $\begin{array}{c}0.36 \pm \\
0.05\end{array}$ & $\begin{array}{c}0.73 \pm \\
0.05\end{array}$ & 0.4 & $\begin{array}{c}59.50 \pm \\
4.5\end{array}$ & $\begin{array}{c}5.55 \pm \\
0.09\end{array}$ & B & $\mathrm{Br}$ & NG & No & 0.67 \\
\hline 16 & Kolahali & $\begin{array}{c}0.72 \pm \\
0.04\end{array}$ & $\begin{array}{c}0.32 \pm \\
0.06\end{array}$ & 2.3 & $\begin{array}{c}59.00 \pm \\
3.6\end{array}$ & $\begin{array}{c}3.43 \pm \\
0.04\end{array}$ & $\mathrm{Br}$ & OW & NG & No & 0.43 \\
\hline 17 & Kon-joha & $\begin{array}{c}0.65 \pm \\
0.07\end{array}$ & $\begin{array}{c}0.24 \pm \\
0.08\end{array}$ & 3 & $\begin{array}{c}46.50 \pm \\
4.5\end{array}$ & - & $\mathrm{Lb}$ & OW & NG & No & 0.45 \\
\hline 18 & Pakikula & $\begin{array}{c}0.72 \pm \\
0.03\end{array}$ & $\begin{array}{c}0.33 \pm \\
0.08\end{array}$ & 2.3 & $\begin{array}{c}49.50 \pm \\
5.6\end{array}$ & $\begin{array}{c}3.27 \pm \\
0.02\end{array}$ & $\mathrm{Bl}$ & OW & NG & No & 0.47 \\
\hline 19 & Sakuwa & $\begin{array}{c}1.04 \pm \\
0.09\end{array}$ & $\begin{array}{c}0.34 \pm \\
0.02\end{array}$ & 3.3 & $\begin{array}{c}71.80 \pm \\
5.4\end{array}$ & - & $\mathrm{Y}$ & OW & NG & No & 0.45 \\
\hline 20 & Bioi & $\begin{array}{c}0.74 \pm \\
0.02\end{array}$ & $\begin{array}{c}0.21 \pm \\
0.03\end{array}$ & 3.5 & $\begin{array}{c}50.20 \pm \\
3.4\end{array}$ & - & $\mathrm{Y}$ & $\mathrm{Br}$ & NG & No & 0.67 \\
\hline 21 & Bahador & $\begin{array}{c}0.82 \pm \\
0.04\end{array}$ & $\begin{array}{c}0.31 \pm \\
0.05\end{array}$ & 2.7 & $\begin{array}{c}55.50 \pm \\
2.3\end{array}$ & - & $\mathrm{Bg}$ & OW & NG & No & 0.78 \\
\hline
\end{tabular}

Note: $\mathrm{UV}=$ Use value; $\mathrm{GW}=$ Grain weight; $\mathrm{Y}=\mathrm{Yellow}, \mathrm{Bg}=\mathrm{Beige}, \mathrm{Lb}=$ Light brown, $\mathrm{Br}=\mathrm{Brown}, \mathrm{Db}=$ Dark brown $\mathrm{R}=\mathrm{Red}, \mathrm{Rb}=$ Reddish-brown, $\mathrm{Bl}=\mathrm{Black}, \mathrm{W}=\mathrm{White}$, $\mathrm{OW}=$ Off white, $\mathrm{Lr}=$ Light red. 


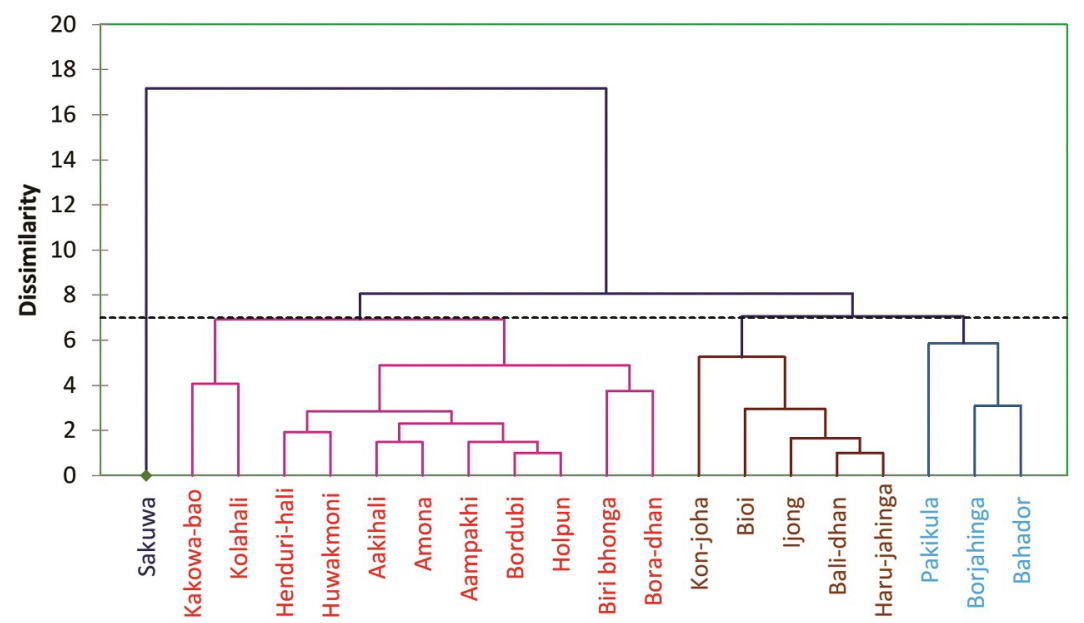

Fig. 2. Dendogram showing variation among the rice landraces based on grains morphological traits. The clusters are displayed with four different shades

\section{Cropping cycle and cultivation of rice}

Assamese farmers strictly maintains the cropping calendar in seek of good outcomes and bumper harvest (Table 2). Further, Fig. 3 portrays different phases of paddy cultivation in this region, which starts with the preparation of field and ends with the storage of newly harvested rice. The New Year of Assamese calendar usually falls on around April 14-15 (celebration of Bohag Bihu). Soon after this festival, farmers prepare themselves for the paddy cultivation. Traditionally, the paddy cultivation comprises of several steps, which includes seed selection (Hos-luwa), field preparation (at the end of April), sowing of seeds in nursery (Dhan-hisa), transplantation (Kothia-rowa) of seedlings, weeding (Dhan-niruwa), harvesting of crops and storing of grains in granary (Bhoral). The transplantation and sowing of rice in nursery however, is restricted to Sali dhan only. The process also includes application of desired organic fertilizing agent such as dung or sewage.

Seed selection process is a mandatory need for paddy cultivation as it directly affects the harvest. Usually, good and healthy seeds are preferred and set aside during the harvest itself and are stored in separate compartment till the next season has arrived. Such constant practice of traditional seed selection process in each generation may lead to permanent attainment of the desired characters. The seeds were subjected to be soaked in water for 1-2 days prior to sowing in selected site (or nursery in case of Sali dhan). Constant weeding further removes the unwanted plants and allow paddy to thrive comfortably. After the harvest, rice grains are separated from the plant with the help of bulls (Morona mora) or are done manually. Prior to their storage, the rice and other grain are generally exposed to the sunlight for drying to ensure their longevity.

Ascertaining the sustainability, the traditional cropping calendar (Table 2), further unveils the intensified management of their agricultural field. As the process was inherited, certain monthly activities are strictly followed and performed each subsequent year. The cropping calendar also includes incorporation of several activities including festivals (Bihu), rituals, home-gardening, agroforestry and mixedcropping.
In the month of October, they celebrate their ritualistic festival Kati Bihu, which usually accompanied by the lighting of traditional lamps in their respective paddy field. This ritualistic festival is usually performed for healthy growth of paddy and bumper harvest. The cropping calendar of this region was completely different in comparison to the neighboring regions where the jhum practices are prevalent (Wangpan et al., 2017).

\section{Insect and pest management techniques}

The challenges and experiences of the preceding years taught many eco-friendly techniques in terms of sustainable farming. The rural farmers follow several traditional ways of pests and insect management. The burning of straw and stubbles reduces the initial inoculums of common pests and diseases. During the study, the locals informed that the grains are usually covered with Colocasia leaves to ensure healthy and early germination. Additionally, the extract of Colocasia and fresh cow dung are used to prevent the attack of worms. Healthy seedlings are usually preferred to debar the early pest infestation. The seedlings are trimmed just before transplanting, due to which the eggs of pest (e.g. stem borer) could be eliminated easily. It was also informed that spraying of lukewarm water on the seedling of Bora rice enhances the growth. The filtrate of Azadirachta indica seeds is used as an insect repellent. Seeds of black cumin are kept near storage and households to prevent rodent attack. Fresh cow dung preparation (about $300 \mathrm{~g} / \mathrm{L}$ ) is sprayed to reduce the leaf related diseases. To manage the attack of pests during storage, the leaf of $A$. indica is placed in several layers between the collected grains. To mislead the rice bugs, saw dust or rice husk of about 6-8 inches' layer are kept upon the seed during the storage. It was also informed that the presence of tiger beetle also controls the population of rice bug. Such traditional practices are proved to be a sustainable method of insect-pest management (Bhattacharjee and Ray, 2010). Besides, the chemical control of rice stem borer can also be successfully substituted by timely releasing of Trichogramma (Upamanya et al., 2013). 
142

Table 2. Cropping calendar and related activities followed by farmers of Lakhimpur, Assam, India

\begin{tabular}{|c|c|}
\hline Assamese Months & Activities performed by farmer \\
\hline Magh & Celebration of Magh bihu. No other agricultural activity has been recorded except harvesting of potato \\
\hline Fagun & Cultivation of Luffa acutangula L., Benincasa hispida L., Abelmoschus esculentus L., Vigna unguiculata L. etc. \\
\hline Soat & Cultivation of jute (Corchorussp.), selection of seeds (both Bao and Sali categories) for next season. \\
\hline Bohag & Celebration of Bohag Bihu. Fields are prepared for paddy cultivation. Cultivation of turmeric and Zingiber officinale. \\
\hline Jeth & Sowing of Bao-dhan (summer rice) seeds directly on main field \\
\hline Aahar & Sowing of Sali dhan in nursery and transplantation of seedling \\
\hline Haown & Transplantation of Sali dhan and cultivation of Capsicum sp. and Zea mays \\
\hline Vada & Weeding (dhan niruwa). Cultivation of Legume like Vigna mungo $\mathrm{L}$. \\
\hline Aahin & Weeding and cultivation of brinjal (Solanum melongena $\mathrm{L}$.). \\
\hline Kati & Celebration of Kati Bihu. Cultivation of potato (Solanum tuberosum L.) and mustard (Brassica sp.) seed. \\
\hline Aaghun & Harvesting of rice commenced. Harvesting of vegetable like Brassica juncea L., Brassica oleracea L., Coriandrum sativum L. etc. \\
\hline Poh & Harvesting and storing of rice grain and Cultivation of potato \\
\hline
\end{tabular}
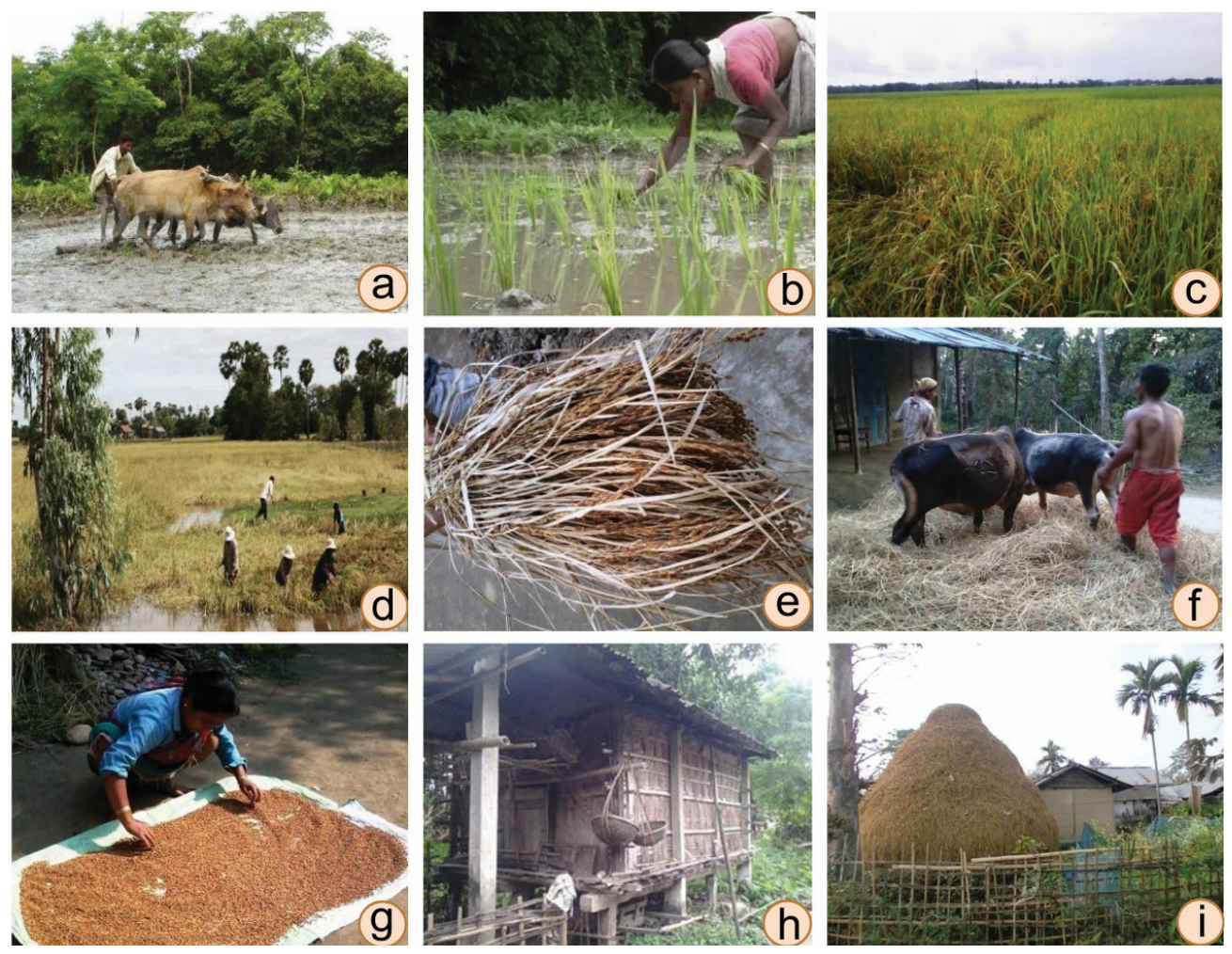

Fig. 3. Phases of Paddy cultivation in Lakhimpur, Assam: a). Preparation of field, b). Transplantation of seedlings, c). Mature paddy field (Sali-dhan), d). Harvesting of Bora-dhan, e). Bunch of harvested paddy, f). Thrashing (Morona), g). sundrying of grains, h) Traditional granary for storage of seeds, i). Pile of straw (fodder for livestock)

\section{Ethnobotanic significance}

Among all, Bora-dhan, recorded with score of 0.89 , was reported with the highest use value (UV) and has proven to be the most useful variety among all. Thus, ethnobotanically, they have a crucial role to play in the context of sustainable development.

Apart from being a staple food, rice based cake, sweets and snacks play a central role in every festive occasion and ceremonies (Fig. 4). Pitha is a traditional cake prepared with the rice flour mixed with varieties of flavoring agents. It is the most popular cake that comes with different flavor (salty and sweet), shapes (round or long) and sizes. Owing to its glutinous nature, Bora-dhan is the main ingredient in preparation of pitha. Based on the flavoring agents used, it may be of several types (Table 3). Snacks (jolpan), on the other hand, are often served as a light meal. Varieties such as Bora-dhan, Ampakhi and Sokuwa are commonly preferred in preparation of traditional snacks (Table 3 ).

Apart from being a central part of diet, many traditional rice landraces are also believed to have medicinal properties and reported to be used as cure against diseases like dysentery, jaundice, breathing problems, epilepsy and chronic gastric patient (Patel and Naik, 2004; Rahman et al., 2006;). Nevertheless, the region has not yet reported on medicinal use of rice. 
After husking, the hulls are collected for it is the main source of fodder for the livestock. After the pounding of rice, the minute particles of rice left behind, may also serve as ready-made fodder. The collected rice straw, on the other hand, is main source of food for cows in every village.

In Assamese tradition, rice is usually associated with wealth and prosperity. The traditional belief and customs practiced by farmers; as well as the major festivals of Assam are linked with the cultivation of paddy. Significant festival, such as Rongali Bihu is performed in the month of April, just before the sowing of rice. Kati Bihu is celebrated in the month of October, when rice plants are in nourishing or growing stage. The post-harvest festival, Magh Bihu, is celebrated in the month of January.

Rice based beverages are stimulating and refreshing drinks, which occupies an important place among the Assamese community. These beverages may be alcoholic and non-alcoholic (Saikia et al., 2007). The nutritious traditional rice-based alcoholic liquor, variously called Haaz or Lao Pani is prepared and consumed after daily hard work as it takes away the day long physical stress. It is prepared in every household and women can be seen actively involved in this process. These beverages also add savour to traditional rituals, ceremonies, merry making, marriages and other gatherings. The preparation of traditional rice beer comprises of two major steps, i.e. preparation of the fermenting agent (mixture of Hazar pitha and leaves of Scoparia dulsis Linn. or Cinamommum glanduliferum Meissn.) and fermentation of Bora rice in Koloh (traditional clay pot).

Table 3. Rice based traditional cakes, snacks and sweets of Lakhimpur, Assam, India

\begin{tabular}{|c|c|}
\hline Food Items & Description \\
\hline Bora-saul & Mixture of boiled Bora-dhan, jaggery and curd (or milk). \\
\hline Chira & It is de-husked rice which is flattened into light dry flakes. These flakes of rice generally get swells when they are added to milk. \\
\hline Muri & The rice grains puff up on throwing in a hot pot having sand. These puffed rice is served with hot milk and jiggery. \\
\hline Hurum & $\begin{array}{l}\text { It is prepared by soaking rice grains for three to four days in water, followed by frying in oil. It is then subjected to pounding in } d \text { heki (a homemade wooden } \\
\text { mill). At last, the properly pounded rice is again exposed into the hot sand and after few minutes of exposure the hurum is ready to serve. }\end{array}$ \\
\hline Sunga-saul & $\begin{array}{l}\text { Dehusked Bora-dhan kernels are soaked for } 2 \text { to } 3 \text { hours in water. It is then put inside an immature bamboo Culm along with little amount of water or } \\
\text { coconut milk. The neck of the bamboo Culm is wrapped with the help of banana leaf. The culm is then roasted on fire and after few minutes sunga-saul is } \\
\text { ready to serve along with curd, hot-milk and yoghurt etc. }\end{array}$ \\
\hline Pithaguri & Rice flour is fried and served with milk, jaggery and banana or jack fruit. \\
\hline Piokh & Pancake prepared from Aampakhi dhan and is served with milk. \\
\hline Til-Pitha: & $\begin{array}{l}\text { It is a type of pancake. Glutinous Bora-saul, is soaked and powdered. Then a certain quantity of this rice flour is baked, filled up with sesame seeds, dried } \\
\text { coconut and dried rind of orange, jaggery etc. and pressed and rolled. }\end{array}$ \\
\hline Ghila-Pitha & The shape of this pitha resembles knee cap (Ghila in Assamese). Fermented paste of Bora-saul flour and jaggery is fried in vegetable oil to make this pitha. \\
\hline Hutuli-Pitha: & $\begin{array}{l}\text { The ingredient of this pitha is similar to Ghila-pitha. However, the only difference is its shape i.e. bi-conical shape that looks like a Hutuli (musical } \\
\text { instrument) after which the pitha was named. }\end{array}$ \\
\hline Bhat-Pitha: & Rice flour is allowed to pass through a sieve in presence of hot steam. It creates small rice chunk which finally shaped into bhat pitha. \\
\hline Sunga-Pitha: & $\begin{array}{l}\text { Rice flour is mixed with water and jaggery to make the paste. The paste of rice flour, water and jaggary is put in to immature bamboo culm, and corked with } \\
\text { banana leaf and roasted over the fire. The bamboo culm shall be removed to leave a solid cylinder of pitha. This is cut into pieces and served with milk. }\end{array}$ \\
\hline
\end{tabular}
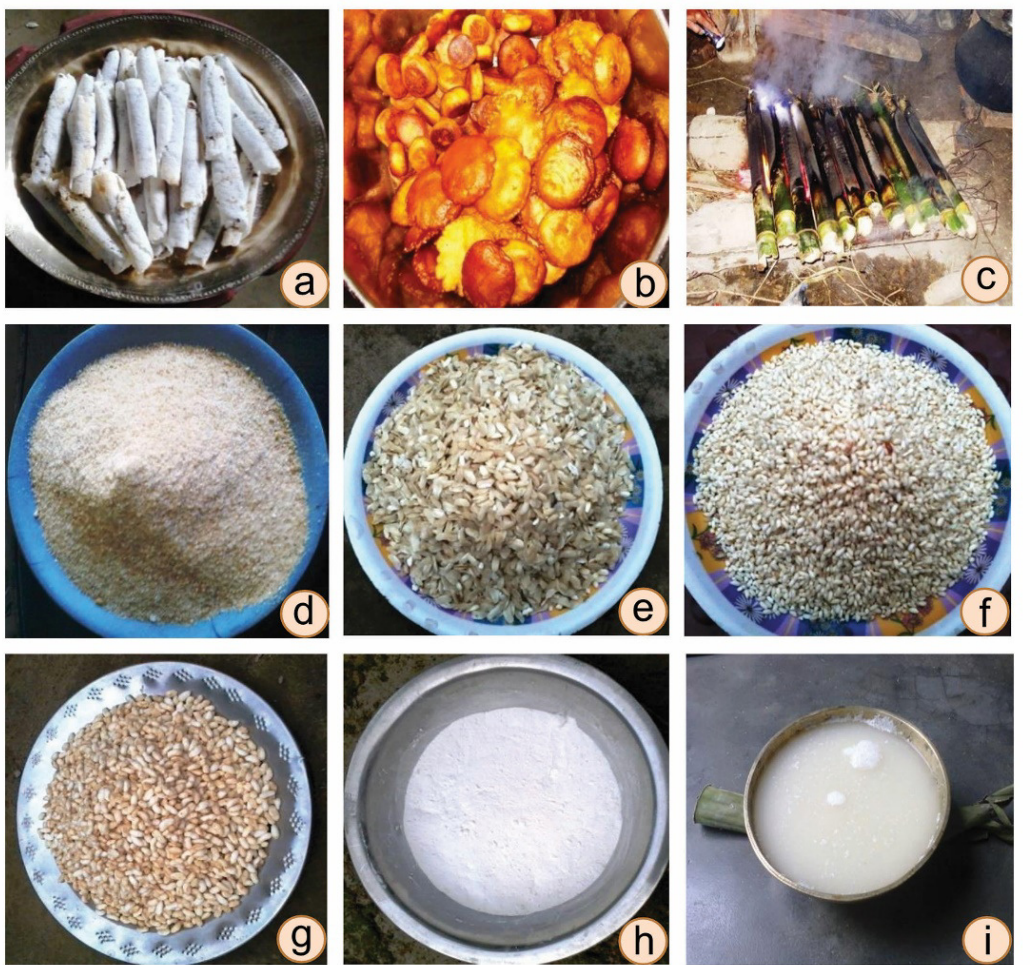

Fig .4. Rice based food and beverages of Lakhimpur, Assam: a. Til pitha, b. Tel pitha, c. Sunga pitha d. Handoh, e. Sira, f. Bora saul, g. Muri, h. Pitha guri, i. Haaz (traditional beer) 
144

\section{Conclusions}

The study reveals profound relationship of people with the traditional varieties of rice. Preservation of the rice germplasm and associated rich traditional knowledge is a challenge and the need of the hour, which needs to be understood by current generations. Before the knowledge is lost under the debris of modernization, the ethnic farmers should be made aware of the management of on-farm conservation of their indigenous crops. Therefore, the intervention of proper scientific approach is obligatory to integrate and coordinate different conservation efforts.

\section{References}

Bhattacharjee PP, Ray DC (2010). Pest management beliefs and practices of Manipuri rice farmers in Barak Valley, Assam. Indian Journal of Traditional Knowledge 9(4):673-676.

Borthakur S, Mishra P, Bortamuly D (2014). Farmers' preference of rice varieties based on varietal attributes recommended by Assam Agricultural University, Jorhat. Journal of Academia and Industrial Research 2(10):556-558.

Das GK, Oudhia P (2001). Rice as medicinal plant in Chhattisgarh (India): Asurvey.Agricultural Science Digest 21(3):204205.

Patel M, Naik SN (2004). Gamma-oryzanol from rice bran oil - A review. Journal of Scientific and Industrial Research 63(7):569-578.

Pfeiffer JM, Dun S, Mulawarman B, Rice KJ (2006) Bio-cultural diversity in traditional rice-based agroecosystems: indigenous research and conservation of Mavo (Oryza sativa L.) upland rice landraces of eastern Indonesia. Environment, Development and Sustainability 8(4):609625.
Rahman S, Sharma MP, Sahai S (2006). Nutritional and medicinal values of some indigenous rice varieties. Indian Journal of Traditional Knowledge 5(4):454458.

Saikia B, Tag H and Das AK (2007) Ethnobotany of foods and beverages among the rural farmers of Tai Ahom of North Lakhimpur district, Assam. Indian Journal of Traditional Knowledge 6(1):126-132.

Upamanya GK, Dutta P, Sarma R, Sarmah AK, Kalita N, Sarma H (2013). Biological management of rice stem borer in the farmer's field of Assam. InsectEnvironment 19(1):73-76.

Veeresh DBK, Vishwanatha S, Anilkumar SN, Satyanarayan R, Halepyati AS (2011). Growth and yield of rice (Oryza sativa L) varieties as influenced by different methods of planting under aerobic method of cultivation. Research Journal of Agricultural Sciences 2(2):298-300.

Wangpan T, Tangjang S, Arunachalam A (2017). Tribal agriculture: tradition in transition in the Indian Eastern Himalaya. Current Science 112(7):1327-1329.

Wangpan T, Tangjang $S$ (2012). Slash-and-burn agriculture in eastern Himalayan zone of Northeast India. Current Science 102(9):12471248.

Wangpan T, Taka T, Tangjang S (2018). On-farm diversity of indigenous rice (Oryza Sativa L.) landraces in border of Eastern Himalaya. Pertanika Journal of Tropical Agricultural Science 41(1):393-410. 